\title{
Learning IFAM by using ITS Medical Centre as a Case: \#1 - Identifying the Function, Medical Service, Infrastructure \& Facility
}

\author{
Vita Ratnasari $^{1, a)}$ \& Hitapriya Suprayitno ${ }^{2, b)}$ \\ ${ }^{1}$ Statistics Department, Institut Teknologi Sepuluh Nopember (ITS), Surabaya, Indonesia. \\ ${ }^{2}$ Civil Engineering Department, Institut Teknologi Sepuluh Nopember (ITS), Surabaya, Indonesia. \\ Corespondance : ${ }^{\text {a) }}$ itaratna70@gmail.com \& b) suprayitno.hita@gmail.com.
}

\begin{abstract}
Nowadays, Infrastructure \& Facility Asset Management (I\&FAM) is essential in Indonesia. Indonesian Law on State Treasury was decreed in 2014, which makes the term I\&FAM still relatively new in Indonesia. Therefore, the researcher must develop about I\&FAM studies, such as doing a practice. For example, the ITS Medical Center (MCITS) use as a case for learning I\&FAM. The first step is to identify the statement of the function, the service, and the infrastructure \& facility. This research used a straightforward method by reading related document and reconnaissance survey. The research produces three principal results, giving medical service for the ITS' community and the surrounding area, and giving another income for ITS. The ITS Clinic occupies a special clinic building of 2 stories high, equipped with a garage, parking lot and a sign. As a facility, the clinic is equipped with a building, the building facilities, standard clinic medical equipment, and an ambulance.
\end{abstract}

Keywords : infrastructure \& facility asset management, ITS Medical Center, function, medical service, infrastructure \& facility.

\section{INTRODUCTION}

In developing countries, Infrastructure and Facility, Healthcare Facility, as hospital and clinic, can be considered as Facility, which should be managed as an asset. Asset Management is already becoming an important matter. In Indonesia, after the instauration of Indonesian Law Number 1 the Year 2004 and Government Regulation number 27 the Year 2014, the Infrastructure and Facility Management need to be well understood and implemented (UU 1/04; PP 27/14). Meanwhile, an international standard on infrastructure asset management and facility asset management have been established as ISO 55000 series and ISO 41000 series. A good understanding and a good practice need to be developed step by step (ISO 55000; ISO 55001; ISO 55002; ISO 41001). Basic Principle of Infrastructure \& Facility Asset Management (I\&FAM) has also been formulated separately in Indonesian Journal of Infrastructure and Facility Asset Management - Jurnal Manajemen Aset Infrastruktur \& Fasilitas (JMAIF) (Soemitro \& Suprayitno 2018; Suprayitno \& Soemitro 2018; Suprayitno \& Soemitro 2019), also in English Wikipedia (Wikipedia 2018; Wikipedia 2019).

Researches on Infrastructure Asset Management have been done a lot. Among others are on the manual development in Korea (Lee, Park \& Kim 2010), on the state-of-the-art of municipal infrastructure asset management in Canada (Halfway, Newton \& Vanier 2005).

Researches on Healthcare Clinic have been done. Among others, these discuss on university clinic as innovative model in Australia (Warner, Jelinek \& Davidson 2017), readiness of nursing student to face clinical practice in Indonesia (Rofiah \& Syaifudin 2014), degree of 
satisfaction of student to university healthcare clinic in Jordania (Alshurideh 2014), and college clinic quality and patient satisfaction in India (Deshwal, Ranjan \& Mittal 2014).

The Institut Teknologi Sepuluh Nopember (ITS) has a Medical Center (MC), which seems run well since several years ago. This ITS Medical Center (ITS-MC) is relatively small but not simple facility. The ITS-MC has a building which can be considered as infrastructure and has quite numbers of medical facilities from static facilities and moving facilities. Meanwhile, not all of the Indonesian universities have a health clinic already. Therefore, analyzing ITS-MC Management by using the I\&FAM Principle will be an excellent case for understanding and developing the theory of the Infrastructure and Facility Asset Management.

This paper presents an attempt to reveal the ITS-MC Function Definition, the Health Care Services, and the Infrastructure \& Facilities in existence. This revelation will serve as the first step to analyze the Infrastructure and Facility Asset Management aspect of the ITS-MC.

\section{RESEARCH METHOD}

The general objective is Learning the I\&FAM by using a Real Case. Analyzing the Health Clinic by using the I\&FAM Principle. For this first step, the analyze is consists of getting the overview, identifying the function statement, identifying the stated medical services offered, and identifying the infrastructure and facilities in existence in general.

\section{LITERATURE REVIEW}

Three Literature Reviews are needed to Learn the I\&FAM of ITS-MC, i.e., the I\&FAM Principle, the Hospitals and Health-Clinics, the University Clinics, and the Hospital Management. This Literature Review is also written for preparing further I\&FAM Research on Hospital and Health-Clinics.

\section{I \& FAM Principle}

I\&FAM, in general, is defined as the program or the knowledge to manage Infrastructure and Facility (I\&F) along is life span in order that the I\&F can always function well, economical, efficiently, effectively, and sustainably, with considering all the major risks possible. The I\&F must also be guarded for always being beneficial for the I\&F owner (ISO 41001; ISO 55000; Soemitro \& Suprayitno 2018; Suprayitno \& Soemitro 2018; Suprayitno \& Soemitro 2019).

\section{Hospital and Health-Clinic}

The principal difference between hospital and clinic can be stated as follow. Hospital is a healthcare facility on the care of inpatients and outpatients for any sickness. While Health-Clinic is focused on the care of outpatients for basic medical care. Thus the clinic is much smaller and simpler than the hospital. For the patient, if the clinic is not able to take care, the patient must be referred to the hospital (PMK 9/14; PMK 56/14; UU 36/09; UU 44/09).

\section{Hospital}

The hospital treats the inpatient, outpatient, and emergency patient in order to recover the health of the patient. The hospital does medical service in terms of sick healing and health maintenance. The hospital must do also referred the patient to the hospital. The hospital's main function, in general, can be mentioned as follows (UU 44/09).

- Organizing medical services

- Service supporting medical and non medical

- Refered service

- Education and training

- Reasearch and development

- General and financial administration 
A hospital can be classified into hospital type and hospital class. The hospital class is related to hospital capacity in bed and the variety and completeness of medical services. By type, the hospital can be classified as a general hospital and special hospital. The general hospital treats various sickness depend on its competence.

In Indonesia, the General Hospital is classified into four classes, depending on its medical services coverage, i.e., Hospital Class A, Hospital Class B, Hospital Class C, and Hospital Class D (PMK 56/14; UU 44/09). The definition of each class is presented below.

- Hospital Class A have facilities and competence to deliver specialistic and subspecialistic medical care.

- Hospital Class B have facilities and competence to deliver at least 11 specialistic medical cares and several subspecialistic medical cares.

- Hospital Class $\mathrm{C}$ have facilities and competence to deliver basic specialistic medical cares.

- Hospital Class D have facilities and competence to deliver basic medical care.

Special Hospital is a hospital focusing on a certain sickness depend on its specialty. Several examples of Special Hospital in Indonesia can be presented as below.

- Cancer Hospital : RS Onkology, Surabaya.

- Eye Hospital : RS Mata Dr. Yap, Yogyakarta.

- Tubercoluse Hospital : RS Paru Dungus, Madiun.

- Psychiatric Hospital : RS Jiwa Prof. Dr. Soerojo, Magelang.

- Neurologic Hospital : RS Pusat Otak Nasional, Jakarta.

$\underline{\text { Health Clinic }}$

The clinic is a Health Service Facility to give personal healthcare service, either basic medical healthcare or specialistic healthcare. Based on the healthcare service, the clinics are classified into Pratama Clinic or Utama Clinic. Pratama Clinic gives basic general medical healthcare service. Utama Clinic provides special healthcare service and/without general healthcare service. The clinic provides healthcare service mainly for outpatient, but certain clinic can serve a limited number or limited case of inpatient. A clinic may be equipped with 5-10 inpatient beds. A clinic can do homecare. A clinic can be developed by the government, by local government, by private (PMK 9/14).

Some examples of Utama Clinic or Specialized Clinic, in Indonesia, can be presented as below.

- Dermatology Clinic : Klinik Pramudia, West Jakarta

- Acupunture Clinic : Klinik Tusuk Jarum, Surabaya

- Orthopaedic Clinic : Bawean Orthopaedic Clinic, Surabaya

- Skin Beauty Clinic : Natasha, Yogyakarta

\section{University Clinics}

University Clinics are common for a big university. Several University Clinics can be presented below (Aljufri 2013; Alshurideh 2014; Ibrahim et al. 2013; Wikipedia 2019; Wikipedia 2019a).

- ITS Medical Center, ITS, Surabaya, Indonesia.

- Unitomo Medical Centre, Unitomo, Surabaya, Indonesia.

- Widyatama Clinic, University Widyatama, Bandung, Indonesia.

- AIT Medical Clinic, AIT, Bangkok, Thailand.

- University Health Center, UTM, Johor Bharu, Johor, Malaysia.

- Institute Hospital, IITM, Madras, India.

- UJ Medical Clinic, University of Jordania, Amman, Jordania. 


\section{Hospital Management}

Hospital Management in Indonesia is regulated by a series of regulation, among others are the Law on Health and the Minister of Health Decree (KepMenKes 129/98; UU 44/09).

\section{GENERAL IDENTIFICATION OF ITS MEDICAL CENTER}

\section{The I \& FAM System Analyse for ITS Health Clinics}

The analyze must be developed step by step, starting from a very general analyze down to more in detail analyze. Tha analyze could follow the following steps :

- General analysis of function, services, and facilities

- Demand analysis

- Supply analysis

- Operation system analysis

- Maintenance system analysis

- Facility analysis

- Manpower analysis

- Financial analysis

- Client satisfaction analysis

- Management system analysis

- Certification analysis

- Etc.

\section{General Overview of ITS Medical Center}

Before 1982, medical services for ITS student was held on the cabinet of dr. Kabat, in Nias Street. Since 1982, by using a room in Jl. Teknik Geodesi R2, a house of Ir. Hoedijono Ismarwanto MT. Medical services were open at 16:00 - 18:00, Monday to Friday, and served by a general practitioner dr. Sulistywati Hoedijono. Since 1998, with the increasing number of student and the increasing number of department, the student medical service has been moved to ITS Staff Dormitory, which has been renovated. General medical service opened morning and afternoon, served by two general practitioners, while one dentist served the dental medical service. Along with the augmentation of student number, the medical service was extended from 09:00 to 19:00, served by three general practitioners and a dentist in the afternoon.

In 2001-2004, there was an addition of medical care as an alternative served by dr. Sulistyowati. In 2004-2006, management by BP ITS was taken over by UPT Fasum, with service hour of 08:00 - 13.00. Starting from 2004, the service was done at ITS Clinic, and it covered the General Clinic and Dental Clinic. The General Clinic was served by a general practitioner, while Dental Clinic was served by a dentist. Apart from the clinic, ITS has a drugstore and Bina Saha Health Laboratory as ITS working partner. The Clinics utilization was not yet optimal, except for General Clinic.

In the 1 July 2006, the ITS Clinic was changed into ITS Medical Center, based on Rector Decree Nomor 3122.1/K03/OT/2006, the management became Technical Working Unit ITS Medical Center. The ITS Medical Center started in operation since 14 July 2006 and has been registered in Dinas Kesehatan with Operation Permit as Pratama Clinic from the Head of the Health Department of Surabaya City No. 503.445/180-KP/P/436.6.3/II/2013. The ITS Medical Center has gotten Certificate ISO 9001:2000 on Quality Management System for Medical Services on 20 February 2007, under Registration Number 717278220024. 


\section{ITS Medical Center Main Function Statement}

It is stated in ITS Medical Center Document that ITS Medical Center TWU (Technical Working Unit) duty is to manage the ITS Clinic. ITS Medical Center job is to do the healthcare for ITS Civitas Academica and the surrounding population as another income for the ITS.

\section{Function}

It is written that the function of ITS Medical Center TWU covers three main functions mentioned as follows.

- Developing the system and healthcare service program.

- Implement coordination and services according to the health facility service system and program.

- Developing the cooperation of healthcare service program with other institutions outside ITS.

\section{Objective}

The general objective of the Clinic Operation is to develop the better access dan quality of the healthcare service for ITS Academic Community and population in East Surabaya region needs healthcare services, all for achieving the high standard health condition.

The general objective can be derived afterward into Special Objective cover four following special objectives :

- The being held of basic healthcare service

- The being held of referred healthcare service

- The being held of healthcare service supporting activity

- The being held of an accurate medical record and a good record of all healthcare activities

\section{ITS Health Clinic Main Health Services}

It is stated in the ITS Medical Center Document that the ITS Medical Center provide 8 Health Services for the ITS Academic Community and the surrounding population. The Health Services cover 8 types of services mentioned below.

1. Emergency Service

2. General Medical Service

3. Dental Medical Service

4. Maternal and Child Medical Service

5. Psychological Medical Services

6. Dermatology and Beauty Service

7. Drugstore Service

8. Ambulance Service

It is also stated that based on the 8 Health Services, the ITS Medical Center should provide 3 groups of regular health activities as follows.

1. Provide health care services for ITS Academic Community and the surrounding population.

2. Provide support for ITS Academic Community big activities, such as the Dies Natalis, the National Day Celebration, and other important activities in faculty or department level.

3. Provide health care services for the surrounding population and the ITS Medical Care patient, such as IHP service - integral health post (posandu) for baby and children, IHP for the aging person, health education, gymnastic training, health seminar, and others.

Based on the healthcare service provided by ITS Medical Center, the ITS Medical Center is classified and is registered as Pratama Clinic. 
(e)ISSN 2656-8896 (p)ISSN 2656-890X

Journal of Infrastructure and Facility Asset Management - Vol. 1, Issue. 2, September 2019

\section{ITS Medical Center Main Facilities}

ITS is situated in the middle east of Surabaya City. While, the ITS Medical Center is located in the middle south of ITS Campus, right on the Arif Rahman Hakim street, facing to the south. The location map is presented in Figure 1 below.

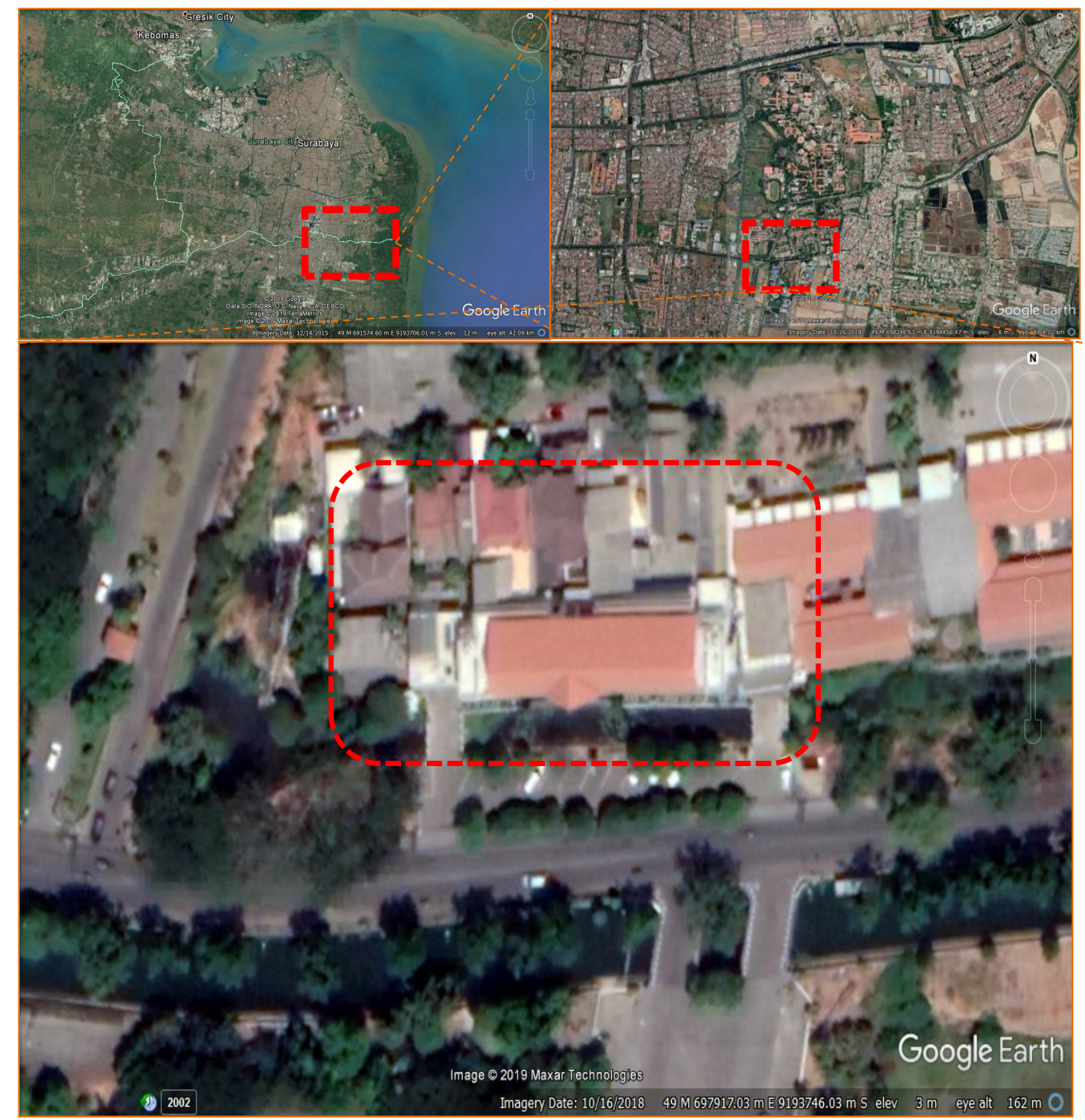

Figure 1. ITS Campus and ITS Medical Center Location in Arief Rahman Hakim Street

ITS Medical Center occupies a Special Clinic building of 6 x 12 sq.meter in 2 stories with Clinic Sign on it. The building is equipped with parking lots for cars, motorcycles, and management's car, and also with a garage for an ambulance. The infrastructure is presented in Figure 2 below. 


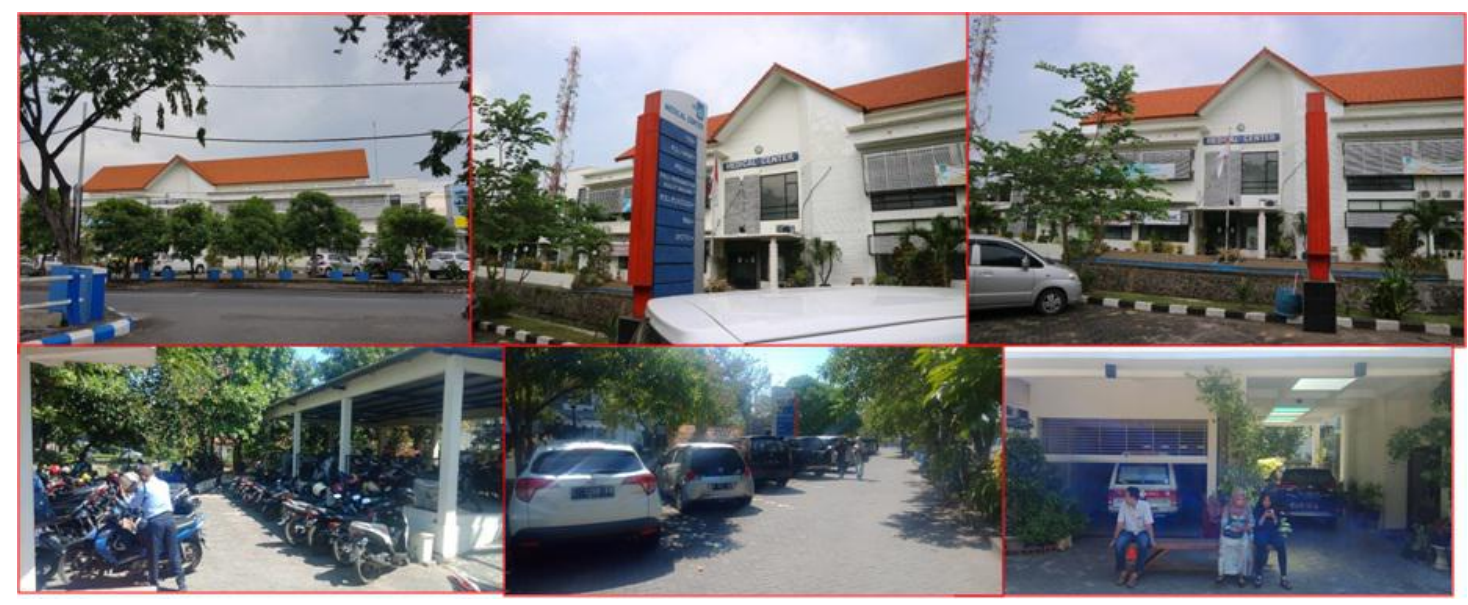

Figure 2. ITS Medical Center Building

ITS Medical Center is equipped with Facilities, mainly consists of static and moveable facilities. The static facilities are an integral part of the building, which consists of electricity, water supply, garbage equipment, lighting, signage, and air-conditioned. While moveable facilities consist of medical practice equipment and ambulance equipment. Several facility photos are presented in Figure 3 below.

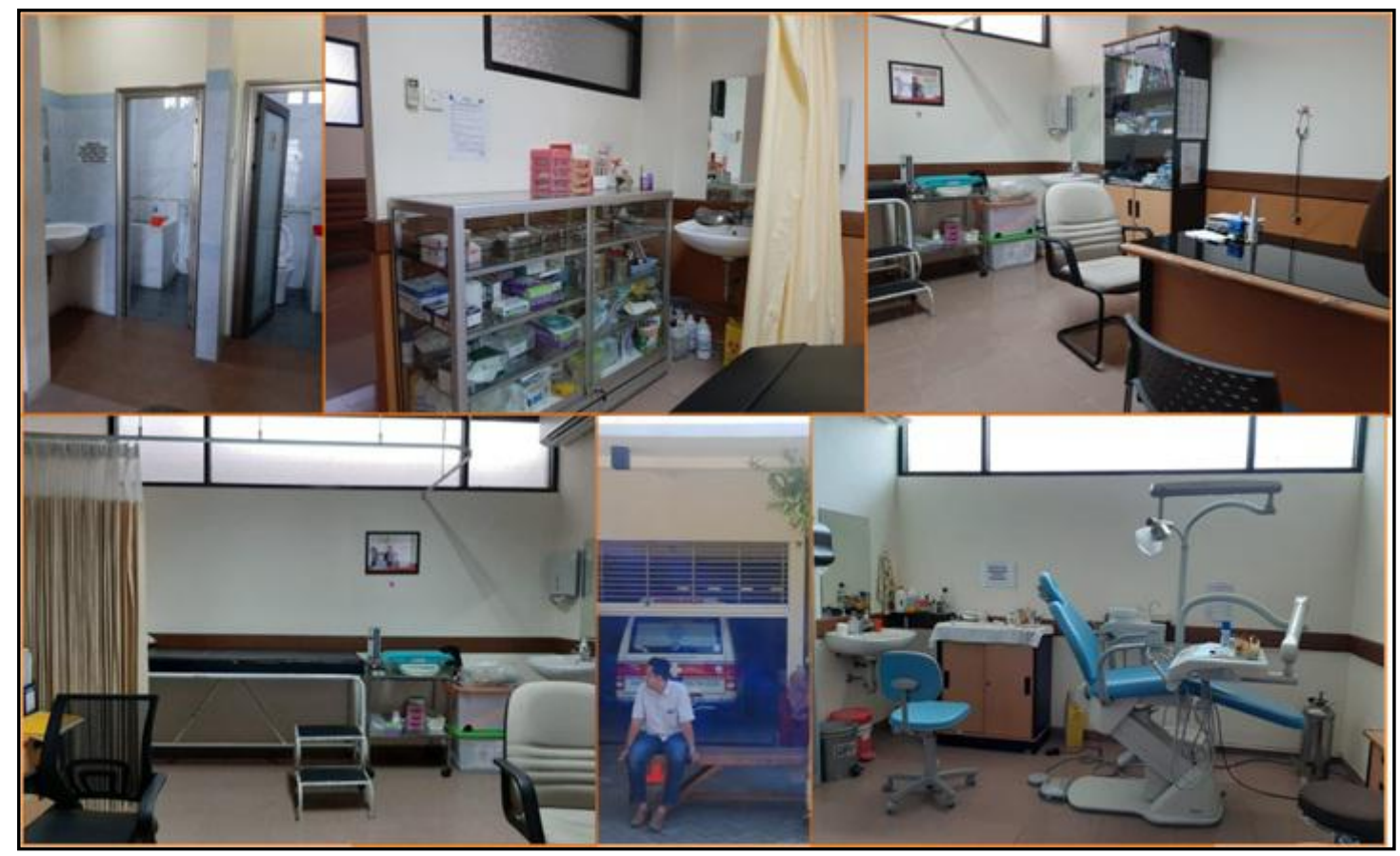

Figure 3. ITS Medical Center Facilities

\section{CONCLUSIONS}

The first step objective, of the I\&FAM Learning, has been successfully fulfilled. Several main conclusions can be drawn below.

- As it is stated, the ITS Medical Care main function is to serve medical services for ITS Community and the surrounding population.

- As it is stated, the ITS Medical Care medical service consists of general medical service, dental service, dermatology and aesthetic service, and psychological consultation service. 
- As gotten from a reconnaissance survey, the ITS Medical Care infrastructures consists mainly of two stories main building, a garage for an ambulance, a car parking lot, a motorcycle parking lot.

- As gotten from a reconnaissance survey, the ITS Medical Care facilities consist of general building facilities, general medical practice equipment, and an ambulance.

To complete, the I\&FAM Learning by using the ITS Medical Care, further analyse need to be done, among others are to analyse whether the existing medical service already conforms to the stated function, to analyse the Clinic Operation System, to analyse the Clinic Demand, to analyse the Clinic Service Supply, to analyse the Clinic Maintenance System, to analyze the Clinic Administration System, to analyze the Clinic Financial System, to analyze the Conformity with the Existing Related Regulation, etc.

Notes. This article is a part of working papers for developing the Theory of Infrastructure \& Facility Asset Management.

\section{REFERENCES}

Aljufri, Alqarana (2013). Aplikasi Rekam Medis Studi Kasus Klinik Universitas Widyatama. Tugas Akhir. Program Studi Sistem Informasi. Fakultas Teknik. Universitas Wdyatama. Bandung.

Alshurideh, Muhammad (2014). “The Factors predicting Students' Satisfaction with Universities' Healthcare Clinics' Services - A Case Study for the Jordanian Higher Education Sector". Dirasat, Administrative Sciences, Vol. 41, No. 2, 2014.

Deshwal, P., Ranjan, V. \& Mittal, G. (2014). "College Clinic Service Quality and Patient Satisfaction”. International Journal of Healthcare Quality Assurance, Vol. 27, No. 6, 2014.

Halfway, M; Newton, L. \& Vanier, D. (2005). "Municipal Infrastructure Asset Management System: State-of-the-Art Review". National Research Council of Canada. Ottawa.

ISO 41001. International Standard ISO 41000. Facility Management - Management System Requirements with guidance for use.

ISO 55000. International Standard ISO 5500. Asset Management-Overview, Principles, and Terminology. First Edition 2014-01-15. International Standard Organization.

ISO 55001. International Standard ISO 55001. Asset Management - Management System Requirements. International Standard Organization.

ISO 55002. International Standard ISO 55002. Asset Management - Management System Guideline for Application of ISO 55001. International Stndard Organization.

KepMenKes 129/08. Keputusan Menteri Kesehatan Nomor 129 Tahun 2008 tentang Standar Pelayanan Minimal Rumah Sakit.

Lee, S-H., Park, S. \& Kim, J.M. (2010). "Suggestion for A framework for a Sustainable Infrastructure Asset Management Manual in Korea". Sustainability 20157 15003-15028, doi : 10.3390/su71115003.

PMK 9/14. Peraturan Menteri Kesehatan Nomor 9 Tahun 2014 tentang Klinik.

PMK 56/14. Peraturan Menteri Kesehatan Nomor 56 Tahun 2014 tentang Klasifikasi dan Perizinan Rumah Sakit.

PP 27/14. Peraturan Pemerintah Republik Indonesia Nomor 27 Tahun 2014 tentang Pengelolaan Barang Milik Negara/Daerah.

Rofiah \& Syaifudin (2014). "Gambaran Faktor-Faktor yang berhubungan dengan Stres Mahasiswa dalam menghadapi Praktek Klinik Keperawatan di Institusi Pendidikan Swasta di Semarang". Jurnal Manajemen Keperawatan, Vol. 2, No. 2, Desember 2014 : 69-75. 


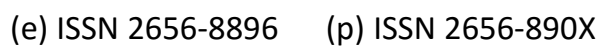

Journal of Infrastructure and Facility Asset Management - Vol. 1. Issue. 2, September 2019

Soemitro, R.A.A. \& Suprayitno, H. (2018). "Pemikiran Awal tentang Konsep Dasar Manajemen Aset Fasilitas". Jurnal Manajemen Aset Infrastruktur \& Fasilitas, Volume 2, Suplemen 1, Juni 2018, hal. : 1-14.

Suprayitno H. \& Soemitro, R.A.A. (2018). "Preliminary Reflexion on Basic Principle of Infrastructure Asset Management”. Jurnal Manajemen Aset Infrastruktur \& Fasilitas, Volume 2, Nomer 1, Maret 2018, Hal. : 1-10.

Suprayitno H. \& Soemitro, R.A.A. (2019). "Reflection on Basic View of Public Infrastructure for Infrastructure Asset Management in Indonesia". Jurnal Manajemen Aset Infrastruktur \& Fasilitas, Volume 3, Suplemen 1, Juni 2019, Hal. : 15-23.

UU 1/04. Undang Undang Republik Indonesia Nomor 1 Tahun 2004 tentang Perbendaharaan Negara.

UU 36/09. Undang Undang Republik Indonesia Nomor 36 Tahun 2009 tentang Kesehatan.

UU 44/09. Undang-Undang Republik Indonesia Nomor 44 Tahun 2009 tentang Rumah Sakit.

Warner, P., Jelinek, H. \& Davidson, P.M. (2010). "A university clinic : an innovative model for improving clinical practice". Australian Journal of Advanced Nursing, Vol. 27, Number 4, June 2010.

Wikipedia (2018). "Infrastructure Asset Management". English Wikipedia. http://en.wkipedia.org/wiki/Infrastructure asset management. downloaded 12/19/2018.

Wikipedia (2019). "Clinic". English Wikipedia. https:/len.wikipedia.org/wiki/Clinic. downloaded 7/4/2019.

Wikipedia (2019). "Asian Institute of Technology". English Wikipedia. http://en.wikipedia.org/wiki/Asian Institue of Technology. downloaded 28/7/2019.

Wikipedia (2019a). "Indian Institute of Technology Madras". English Wikipedia. https://en.wikipedia.org/wiki/Indian Institute of Technology Madras. $\quad$ downloaded 28/7/2019. 
(e)ISSN 2656-8896 (p)ISSN 2656-890X

Journal of Infrastructure and Facility Asset Management - Vol. 1, Issue. 2, September 2019 
(e) ISSN 2656-8896 $\quad$ (p) ISSN 2656-890X

Journal of Infrastructure and Facility Asset Management - Vol. 1. Issue. 2, September 2019 